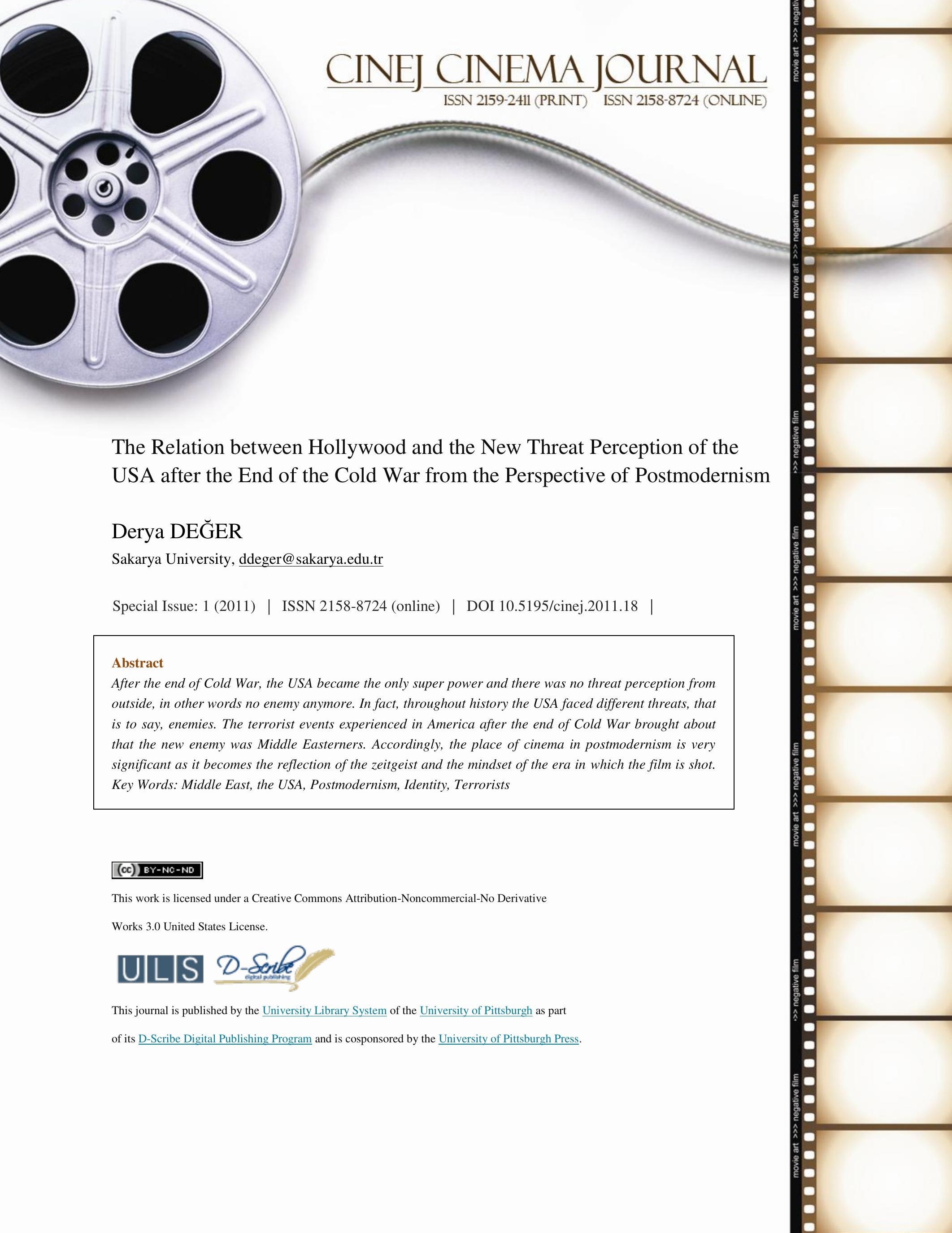




\section{The Relation between Hollywood and the New Threat Perception of the USA after the End of the Cold War from the Perspective of Postmodernism}

\section{Introduction}

The States appeal to the media to make their foreign policy decisions and their acts gain legitimacy. They should be very careful while choosing the right image to make their message reach the public in the correct way. The U.S. can be claimed to be the only country using this method frequently. As one of the important tools of the media, the cinema is an effective means.

There is a reciprocal relation between Hollywood and the US government. In consequence the policy goals of the U.S. are transferred to all people as they are right in each of their actions. It resembles reality instead of being the real reality. It further means they create an image and people begin to believe in this image in the long run as it is the real reality, although it is not. Film themes of Hollywood change according to the policy of the era. While in the 1950s the theme was Nazis, in the 1980s it was communists. And today it is Middle Easterners and terrorists. Hence it can be said that Hollywood reflects the policy of the president of the USA in office.

Deriving from the above facts, the aim of the study is to show whether there is a mutual relation between Hollywood and the U.S. government or not and how the films contribute to the creation of the perception of threat from the perspective of postmodernism and during this process how the USA needs the Middle East to be seen as a threat especially after the end of the Cold War to recreate its identity and show its power especially in the presidential term of Bill Clinton.

This study tries to make clear in which way the problems mentioned above are products of postmodernism. The Hollywood film on the Middle East named The Siege (1998) will be analyzed from the perspective of postmodernism in IR and concerning how the U.S. appeals to films, and needs the Other and a threat to create an identity and find a legitimate base for its actions.

Hereby, it can be suggested that as formerly known there is both a close and a mutual relation between Hollywood and the policies of the President of the era. Although Clinton had a milder policy in the Middle East, the events experienced within the nation during his presidency made the citizens of America feel the threat of terrorism at their home. The images depicting the Middle Easterner are always what they, the Americans, are not. Via this the U.S. creates its identity by oppressing the Other, and thus the U.S. strengthens its power once more (Deger, 2011).

\section{The Middle East as a New Enemy and the Foreign Policy of the USA towards the Middle East Region after the End of Cold War}

The definition of the Middle East is quite problematic. The term itself does not just tell us about the geographical region but also about a psychological area and/ or a cultural area. The Middle East is a widely used term which does not have a certain definition. Briefly, it covers a vast territory (Gerges, 1991: 209), and takes attention of many states and the Western-dominated world system (Hinnebusch and Ehteshami, 2002).

The real interest of the USA for that purpose is shown in many sources as "controlling Middle Eastern oil, protecting Israel, targeting unfriendly government and most ominously dominating the world" (Looney, 2009: 4) 
Thus as Edward Said (1978) states the Middle East is dominated by the interest of the colonial powers and so the relation between the West and the East is a kind of relation of power and domination.

During the Cold War, the region became the focus point of the global rivalry. Thus, with the Cold War, France and Britain were pushed out and the USA and the USSR brought in (Halliday, 2005). So, the more the Cold War intensified and spread, the more the importance of the region increased (Hansen, 2000:17) In fact, during and after the Cold War the region occupied a center stage for external powers (Fawcett, 2005). With the end of Cold War, the end of bipolarity is seen and the United States has become the only super nation which has the capacity to interfere in each region of the world (Kissenger, 2006). The new era is defined as "the end of history" by Fukayama and "the clash of civilization" by Huntington. The world entered a new era and the new era was called an era of rivalry; civilization, culture and religious being the sources of conflict (Huntington, 1996). With the collapse of the Soviet Union the Cold War came to an end, and, hence, this induced the restructuring of the international politics of the Middle East region. The end of the Cold War collides with the invasion of Iraqis to Kuwait on 2 August 1990. So, it is very easy to see the changing balance in the region and how the USA is effective in the Middle East (Halliday, 2005).

Shortly after the end of the Cold War, William "Bill” Clinton was elected President of the United States of America for the period of January 1993 and January 20, 2001. Hence, he became the first president after the end of the Cold War. It is asserted that during the Clinton administration, the U.S. enjoyed more peace and economic well being than at any time in its history (The White House, nd).

When the Cold War was over, Americans needed a foreign policy that would recognize the new world before them. Thus, under the Clinton doctrine of enlargement, the United States would try to spread democracy and free markets. (Maynes, 1993-1994: 3-4). The Clinton doctrine actually does not mention preemptive action but talks about maintaining "a robust triad of nuclear forces to deter potential adversaries who might seek access to, or use of, WMD and building a missile defense system to protect against rogues states with WMD” (Offner, 2007: 38).

Clinton defined that threat elements for America have become various: terrorism, spread of weapons of mass destruction, organized crime, drug traffic, ethnical and religious hatred, attacks of rogue counties and environmental corruption. If today they ignore these problems, tomorrow they will have to abide all of the results (Hirsh, 2003). In his presidential terms Clinton handled Middle East policy on the issues such as controlling the oil springs in this region, carrying the oil to the world market, reducing the effects of Radical Islam, and depriving the countries in the Middle East region from WMD. In short, whether taking an active role or not in the foreign policy, the Middle East region has been an important region for the USA.

In fact it can be said that the interest of the USA in the Middle East began in the 1920s. After oil had been discovered in the Middle East in the 1920s, US oil companies began to get interested in this region in order to have a share in this oil. But the real interest of the USA, both militarily and politically, in this region began after World War II. In 1990, after the collapse of the USSR, Iraq and Iran were realized as a new threat. (Ural, 2009).

America perceived this era as "New World Order", which contained the USA's military, political, diplomatic, judicial, technological, economical and commercial supremacy over the world. In order to preserve this new world, the USA would interfere in any attacks aimed at demolishing this order. For these reasons the USA began to define its new policy in order to remove these new threats. Concepts such as liberal democracy, universal peace, and respect to human rights have become the concepts to be used in the New World Order by the USA. 


\section{Postmodernism in International Relations (IR): The Interaction between the US Foreign Policy and Hollywood}

In order to legalize the action carried by the President in the public eye, governments usually appeal to the media. Among the other states, the USA is the most successful state in doing this via the media, especially the cinema. Having Hollywood, the most effective institution, the US governments have been trying to legalize their actions since the first emergence of the film.

Cinema, which is a significant element of postmodernism, is very effective in creating an image in people's minds. It doesn't play a neutral role in the production of information or its transmission or reflecting the outer reality. The states make the dangers and threats from outside felt by its people. Nevertheless, it can be said that cinema presents scenes, illusions, archives scenes and simulations resembling the reality instead of the real reality. In order to create their identity, the state needs the media, especially the cinema. For these reasons there is a close relationship between the US government and Hollywood. As a result "a shift of perspective" occurs (Braidotti, 1996: 1).

In this respect the emergence of American postmodernism can be seen in "New Times politics in the late 1980s and early 1990s with its interest in consumerism, identity, ethnicity and with the critique of essentialism, be relation to gender, class, or ethnicity" (McRobbie, 1994: 521). Considering these facts, it can be said that as one of the elements of popular culture "cinema" is to reflect, to expose and highlight our cultural beliefs and values in this way.

It is thought that the power politics reality is generally formed through textuality and representations (Devetak, 2001: 186). Textuality, which stems mainly from Derrida, is a common postmodern term. By using text, (in fact, Derrida means the world is like a text, that is, the real world is formed like texts are), no one can attribute to this real world without an interpretive experience. For this reason, postmodernism gives importance to interpretation to constitute the social world (Devetak, 2001). Derrida uses the statement by Montaigne to make clear that people need to interpret interpretations more than to interpret things (Derrida, 1978). All the same texts are compared with other similar texts. For this reason the definition of the concept of representing reality becomes difficult as it is not definite and clear what, if any, reality is objective (Klimenkova, 1992). Thus, in order to scrutinize textual analysis, deconstruction and double reading are two significant methods in postmodernism. According to this view, there is an inevitable hierarchical relation between two opposed terms; as a result, one side becomes the privileged side, whereas, the other becomes the subordinated term.

Despite postmodernism's impact on historical scholarship, which has appeared in the U.S. foreign policy studies since the 1970s, it has not gained much attention by the profession; we can observe its usage in the construction of national identity readily. That is to say, the U.S.' endless wars against enemies and others are serving to strengthen the national identity and overcome the periodic crises suffered by the country snugly. As Joan Hoff (19??) emphasizes, when a country suffers from a doubt on national identity, or in other words, psychic crisis, the country prefers war in order to prove national identity and a short term therapeutic relief from psychic crisis is gained. Thus the state always bases its foreign policy on the existence of "outer enemy nations" or "outer threats". They are essential for the inside to built a common "us" and "friendship". For this reason in order to create an identity a boundary between "inside" and "outside", "self" and "other", "we" and "they", and "domestic" and "foreign" are needed to be fixed. That is, "they" are the ones who "we" are not. Therefore, as it is understood, political identity requires prevailing discourse and practices of security and foreign policy. 
The states take the advantages of promotion process in order to make their foreign policy decisions and acts gain legitimacy. For this reason they often appeal to the media. After the end of the Cold War the United States, as a sole power, used the media effectively to shape and form the system according to its policy, to preserve its power and to gain legitimacy in front of the eyes of the public while doing these. Thus Hollywood is one of the most use ful tools for the U.S. to transfer the mindset to the public. Through its visuality and the capacity of access to all over the world, the intended message of the U.S. can reach a great deal of people. Thus we can say that cinema is one of the political tools within the power system of today.

It is believed by many people that there is a close relationship between the United States government and Hollywood directors to choose the dialogues in the scenario, actors and actresses, the places, and the created enemy. As a result Hollywood turns into a tool by which the life style and policy goals of the U.S are transmitted to all people. "With Soviet pretensions shattered and aliens from outer space passing, the new cinematic enemy is the Muslim extremist." (Fries, 2005: 303). Parallel to this, after the end of the Cold War, Hollywood began to fight against international terrorism and dictatorial regime's nuclear arms traffic in the 1990s. Among the products of the media, cinema can be claimed as the most effective one to present the Middle East and the Middle Eastern policy of the United States. The American cinema (Hollywood) has been productive in producing films around the theme of the Middle East (Khatib, 2006). In fact, the perception on Arabs in the films to be terrorists, appeared on the silver screen long years ago, as seen in Sirocco (1951), Wanted Dead or Alive (1986) and True Lies (1994). Middle Easterners always became easy targets.

In Hollywood films it is easily seen that there is an absolute and systematic differences between the Orient, in other words, the East, which is shown as irrational, underdeveloped and inferior, and the West, which is shown as rational, developed and superior. The West is the opposite of the Orient, which is something to be feared and controlled (Khatib, 2006). In this way Hollywood films create a misleading among people, especially Americans, to believe that all Middle Easterners or "Arabs are terrorists and that they do not value human life as much as we do" (Shaheen, 2001: 29).

It is also claimed that the East is characterized by how the West writes about the East. As Shaheen quotes the worlds of Platon from the Book of Republic: "Those who tell stories also rule the society" (Shaheen, 2001: 5). In this way, the thoughts in our minds and our beliefs are shaped according to the sovereign power (Gerges, 1991). That's why the representation of Arabs in Hollywood films can be associated with preserving the status quo of the United States as a world policeman controlling, among others, Arabs and Arab countries (Khatib, 2006). In the films the US is always presented as the initiator of peace talks in the Middle East. Hence, America is being put in a superior position, whereas the Middle Easterners are being put in an inferior position; America is almost infantilizing Middle Easterners such as in the films The Ambassador (1984) and Programmed to Kill (1987).

In those films there is not any distinction made between the notions of Arabs, Muslim and Islamic fundamentalists. "Hollywood tends to blur not only Arab countries, but also Islamic fundamentalism and Islam as a religion with those countries and others in the Middle East region" (Khatib, 2006: 175). They are all seen as the Other, that is, the enemy (Campbell, 1998). "In contrast to the degeneracy of the Arab/ Muslim/ fundamentalist Other, the United States in Hollywood stands superior, morally right, and unbeatable" (Khatib, 2006: 167). All terrorists are associated with speaking Arabic; and Islamic prayers are associated with preparation for terrorist acts in Hollywood films. Arabs are depicted as the ones who kill, kidnap, and torture. The films seem to depend on historical facts to depict these acts.

In short, Hollywood has been using the images as a tool for cultural defense and has become a space for political metaphor. Here American foreign policy is a dominant discourse. Ponder the consequences. The negative 
images of the Middle Easterners as a threat are seen to be the reflection of the president's policies of the era to recreate an identity and show the strength of America to the world (Deger, 2011).

\section{Overview: Hollywood Films and Threat Perception in Clinton's Presidential Years}

Terrorism is well known by American citizens. However, it was for the first time that it really hit the American citizen's consciousness when the Iranian hostage crisis occurred in 1979. In the hostage crisis Iranian students took over the American Embassy in Tehran and took several embassy employees hostages. In Delta Force (1986) we can see the clues of this event.

In the 1990s terrorists hit the United States on its own soil. The World Trade Center was bombed by a Middle Eastern terrorist; as a result six were killed. Two years later, on April 19, 1995 the federal building in Oklahoma was bombed and consequently a hundred and sixty-eight Americans died. "Though no American of Arab descent was involved, they were instantly targeted as suspects" (Shaheen, 2001: 7). During the presidential term of Bill Clinton the country felt the threat of terrorism on their soil through the terrorist attacks in 1993 and 1995, and this resulted in the killing of many innocents (Lader, 2009: 246).

This has become a turning point for the perception of threat. Now there is an enemy threatening the mainland of America as we see in Under Siege 2: Dark Territory (1995). The media focused on the new threat immediately. As the Middle Easterners have always become easy targets Arabs are seen in Delta Force One: The Lost Patrol (1999). Thus the fear of terrorism has begun to be felt by American citizens as it was so close to their home. Until this time, from the end of the Cold War to these attacks, the U.S. had not had a clear enemy. So, it was difficult to display their identity. It was difficult for Hollywood to depict a believable screen villain without a real threat. It will be useful to look at the film The Siege (1998) to understand this relation.

The Siege is an action thriller drama released in 1998. It is mainly about the Islamic militants unleashing terrorism in New York City. The film was shot during the Clinton presidency. Although the president is not named in the film, it can be easily understood that the film was colliding with the era of Clinton as he is seen on TV in the film. The Siege shows us the threat of terrorists in the mainland of America; the danger has reached home. The terrorist attacks do not stop; the number of the attacks is increasing day by day. They have been made firstly on a bus, then a theatre, a kinder garden and the Federal Plaza. As a result the President announces the martial law. Major General Devereaux of the Army's $101^{\text {st }}$ Airborne Division (Bruce Wills) is arrested; finally, the martial law ends and detainees are released (The Free Encyclopedia, 2010).

In the film the dialogues give us a clear idea of American thought on the Middle East region. Although the exotic and mysterious side of the Middle East is depicted with some of the dialogues, such as "My first boyfriend was Palestinian," "My father used to say Palestinians seduce you with their suffering," "there's these incredibly warm, hospitable people, living in this horrible place", and "I love Lebanese men," and "growing up there (in Beirut) was like paradise, like an exotic Paris", the many other dialogues show us the dangerous side of this region.

What is more, in the film there is an emphasis on the word "jihad". It is understood by "(Arab terrorists) pros" as having "a warrant from god", "from the age of 12, they've been dodging people like you, people better than you." Thus the West labeled the word "jihad" with fundamentalist Islam and terrorism. Hence, jihad gains the meaning by the West of a Muslim war against infidels. 
Moreover, in this film it is taken into consideration that the dialogues in Arabic language seem to be no worth of being translated into English. It can be claimed that the dialogues of the Arab characters in the film have been seen as irrelevant.

Above all, the politicians' views upon the attacks of the terrorist are relevant because what they say is important in order to see how much the policy of the country is against the Middle Easterners. Clinton (scenes on the TV news suggest that it is his era) says about the bombings "Let me say again. America takes care of our own. Those who did it must not go unfinished"; and next, "the cowards who committed this murderous act must not go unpunished" and "the explosions appear to be the act of terrorists. I'm outraged by the terrorist act." Reporters state about the bus explosion "Beirut came to Brooklyn today when the worst terrorist bombing in the United States since Oklahoma City took the lives of more than people". Via this way, in the minds of people, both, the thought of the threat at home is emphasized and the threat discourse about Muslims and Arabs is shaped. In addition, throughout the film it is continually stressed that the terrorist attacks are aiming at the way of American way of life. Americans begin to live in suspicion and fear. Putting the emphasis on the terrorist cells, it is shown that the threat is at home and "one cell controls all others. Cut off the head, the body will wither" is an old wisdom and not working anymore. The new wisdom is "each cell operates independent of the other. Cut off one head, another rises up in its place". Thus these attacks will not have an end. (Oumlil, 2010).

The film gives a wide space to the news on TV to make the events displayed look objective to the viewers. Terrorist attacks on the external representations of America are shown on the TV news. The new enemy of the U.S is global Islamic terrorists. They are Muslims, and generally negative stereotypes have been used to describe them. They are depicted as bearded, using prayer beads and skullcaps, reading the Koran and going to the Mosque. Whenever a Middle Eastern is on the scene the azan is being recited and its sound is heard or this man is performing the namaz. Under an armed conflagration, while no American is killed, all the terrorists are killed; thus showing the superiority and power of American army one more time. Moreover, by comparing the differences between the way of life of Americans and Islamic terrorists, the superiority of America is emphasized. However, "the FBI ends up arresting the last terrorist and the Army general in charge of the operation for anti-constitutional practices" (Valantin, 2005; 54). Though The Siege criticizes the role of the U.S. government and military in counterterrorism in the case of the country under a threat on its own soil, the film supports the prevailing order. With the help of the protagonist FBI agent the government beats the terrorists and the general who treats the innocents viciously. Thus, the U.S. has tried to secure its own country and the whole world from these attacks and fears, and at the same time it has punished those guilty of spreading this fear. By doing so the U.S. keeps its protector role for peace in the world (Deger, 2011).

\section{Conclusion}

The States principally take the advantage of the media while reshaping their foreign policy. The United States of America can be said to be successful in reshaping the mindset of the era. Hollywood is successful in reflecting the zeitgeist and making the audience interpret the American philosophical thought as well. In any case, there is "a general consensus that Hollywood films are complex cultural documents which speak either implicitly or explicitly to the concerns and preoccupations of their own moment of production" (McCrisken and Pepper, 2005: 2).

As a result there is a mutual relationship between Hollywood and the U.S. government. In this way, the government defines its identity and legitimizes its actions; while Hollywood does not reflect the actual reality but something resembling the reality. That is to say, "the enemy (Other) and the hero (America) have been strained from 
the text of the scenarists of Hollywood" (Alatl1, 2009: 13). As Derrida asserted the world is something like a text and can be understood through an interpretive experience. Postmodernism or the tool of postmodernism cinema makes us interpret the world. It means that Hollywood makes us interpret the discourses of the foreign policies of the presidents.

In order to understand this world, as Derrida affirmed, we need close reading which means double reading and also deconstruction both of which are indispensable parts of postmodernism. With The Siege deconstruction's main focus is easily seen. The film emphasizes on "We" and "They", "Us" and "Other", "the West" and "the East", "Men in the West" and "Men in the East", "Women in the West" and "Women in the East", and "Men" and "Women." Thus the opposition puts the former side to the privileged position, while it puts the latter side to the subordinate position (LaBranche, 2002). As the first president after the end of Cold War President Bill Clinton in fact needed these threats and dichotomies in order to strengthen the US' identity and find a legitimate base for their actions. For this, the USA takes the advantage of cinema, that is to say, Hollywood. Being in a close relationship with Hollywood, the USA government can easily transfer its message to people. Therefore, they carefully choose the target and discourses. The new target is the Middle Easterners. When depicting them generally negative images are used. Especially the terrorist attacks in the early 1990s turned the attention towards them (Deger, 2011). 


\section{References}

Alatli, A. (2009). Hollywood'u Kapattığım Gün (Amerikalılara Çok Büyük Bir Iyilik Yaptım) Kaan'ın Kitab1, Everest Yayınları, İstanbul.

Alsultany, E. (2008). The Prime-Time Plight of the Arab Muslim American after 9/11: Configurations of Race and Nation in TV Dramas, in Jamal, A. and N. Naber (Eds.), Race and Arab Americans Before and After 9/11: From Invisible Citizens to Visible Subjects (pp. 204-229), New York: Syracuse University Press.

Aronowitz, St. (1989). Postmodernism and Politics. Social Text, Universal Abandon? The Politics of Postmodernism, Duke University Press, No. 21, http://www.jstor.org/stable/827808, 07/10/2010, pp. 46-62.

Barker, Chr. (2000). Cultural Studies: Theory and Practice; with a Foreword by Paul Willis, London: Sage.

Bleiker, R. (2000). Popular Dissent, Human Agancy and Global Politics. Cambridge.

Bozkurt, G. S. (2006). ABD’nin Orta Doğu Politikası. In Sandikli, A., and K. Dağc1 (Eds.), Büyük Ortadoğu Projesi, İstanbul: Yeni Oluşumlar ve Değişen Dengeler.

Braidotti, R. (1996). Cyberfeminism with a Difference, http://www.let.uu.nl/womens_studies/rosi/cyberfem.htm, 15.07.2010, pp.1-14.

Campbell, D. (1998). Writing Security, United States Foreign Policy and the Politics of Identity. Manchester University Press.

Değer, D. (2011). Hollywood Films Reflecting Middle East Policy between 1993 and 2008, Unpublished MA Thesis, Sakarya University, Institute of Social Sciences.

Derrida, J. (1978). Writing and Difference, Henley.

Devetak, R., et al. (2001). Postmodernism. Theories of International Relations. 2nd Edition, Palgrave, England,,pp. 181-208.

Dixon, Wh. W. (2004). Something Lost - Film after 9/11. In Dixon, Wh. W. (Ed.), Film and Television after 9/11, the Board of Trustees, the United States of America.

Doty, R. L. (1996). Imperial Encounters, Borderlines Volume 5, University of Minnesota Press, London.

Fawcett, L. (2005). International Relations of the Middle East, Oxford University Press.

Folker, J. St., \& Shinko, R. E. (2005). Discourses of Power: Traversing the Realist-Postmodern Divide. Millennium-Journal of International Studies, pp. 637.

The Free Encyclopedia (2010). http://en.wikipedia.org/wiki/The_Siege, 15.07.2010.

Freedman, R. O. (1999). U.S. Policy toward the Middle East in Clinton's Second Term, Meria Journal, Volume 3, 1 March, http://meria.idc.ac.il/journal/1999/issue1/jv3n1a5.html, 15.07.2010.

Gerges, F. A. (1991). The Study of Middle East International Relations: A Critique, British Journal of Middle Eastern Studies, Vol. 18, No. 2, pp. 208-220. 
Haas, R. N. (1997). Fatal Distraction: Bill Clinton's Foreign Policy, Foreign Policy, Carnegie Endowment for International Peace, No. 108, Autumn, pp. 112-123 http://www.jstor.org/stable/1149093, 22/05/2009, pp. 112-123.

Halliday, F. (2005). The Middle East in International Relations: Power, Politics and Ideology, Cambridge University Press.

Hansen, B. (2000). Unipolarity and the Middle East, London: Curzon.

Havis, A. (2010). American Political Plays after 9/11, the Board of Trustees, Southern Illinois University, the United States of America.

Hinnebusch, R., \& Ehteshami, A. (Eds.) (2002). The Foreign Policies of Middle East States, London: Lynne Rienner.

Hirsh, M. (2003). At War with Ourselves: Why America Is Squandering Its Chance To Build A Better World, Oxford University Press, New York, the United States of America.

Hoff, J. (19??). American Diplomacy from a Postmodern Perspective, The Journal of the Society for Historians of American Foreign Relations.

Huntington, S. P. (1996). The Clash of Civilizations and Remaking of World Order, Simon \& Schuster.

Jarvis, D.S. (2000). International Relations and the Challenge of Postmodernism: Defending Principle, Columbia: University of South Carolina Press.

Karadoğan, A. (2005). Postmodern Sinema mı Film mi?, İletişim Araştırmaları, 3 (1-2), pp. 133-160.

Khatib, L. (2006). Filming the Modern Middle East, Politics in the Cinemas of Hollywood and the Arab World, London.

Kissinger, H. (2006). Diplomasi, İ. H. Kurt (Çev.), İstanbul: Türkiye İş Bankası Yayınları.

Klimenkova, T. A. (1992). Feminism and Postmodernism, Philosophy East and West, Moscow Regional EastWest Philosophers' Conference on Feminist Issues East and West, University of Hawai'i Press, Vol. 42, No. 2, April, http://www.jstor.org/stable/1399291, 29/03/2010, pp. 277-285.

Labranche, St. (2002). Rex the Dog Can Bite: A review of Postmodernism in International Relations (1989-2000), The Review of International Affairs, Vol. 2, No. 2, Winter, pp.63-78.

Lader, C. (2009). Painless American History, 2nd edition, Barron’s Educational Series, the USA.

Levy, P. B. (2002). Encyclopedia of the Clinton Presidency, Greenwood Press, the USA.

Looney, R. E. (Ed.) (2009). Handbook of US-Middle East Relations: Formative Factors and Regional Perspectives, London and New York: Routledge Taylor and Francis Group.

Maynes, Ch. W. (1993-1994). A Workable Clinton Doctrine. Foreign Policy, Carnegie Endowment for International Peace, No. 93, Winter, http://www.jstor.org/stable/1149017, 22/05/2009, pp. 3-21.

McCrisken, T. B., \& Pepper, A. (2005). American History and Contemporary Hollywood Film, Edinburg: University Press Ltd, Edinburg.

McRobbie, A. (1994). Feminism, Postmodernism and the 'Real Me', Postmodernism and Popular Culture, London. 
Metz, A. (2002). Bill Clinton: A Bibliography, Greenwood Press, the USA.

Offner, A. A. (2007). Liberation or Dominance? The Ideology of U.S. National Security Policy. In Bacevich, A. J. (Ed.) (pp. 1-53), The Long War: A New History of U.S. National Security Policy Since World War II, Columbia University Press, the USA.

Oumlil, K. (2010). Arabs and Muslims in Hollywood: Breaking down the Siege, http://www.interdisciplinary.net/ptb/hhv/vcce/vch7/Oumlil\%20paper.pdf, 10.06.2010.

Said, E. W. (1978). Orientalism. New York: Vintage Books.

Shaheen, J. G. (2001). Reel Bad Arabs: How Hollywood Vilifies A People, New York: Olive Branch Press.

The Siege (1998). Dir. Edward Zwick, Perf. Denzel Washington, Annette Bening, Tony Shalhoub with David Proval and Bruce Willis, 20th Century Fox and Bedford Falls Productions.

Smith, St. (1997). Postmodernism and International Relations Theory: A Reply to Østerud. Journal of Peace Research, Sage Publications Ltd., Vol. 34, No. 3, August, http://www.jstor.org/stable/425166, 07/10/2010, pp. 330-336.

Ural, A. (2009). 11 Eylül Sonrası ABD’nin Ortadoğu Politikası ve Türkiye’ye Yansımaları, İstanbul.

Valantin, J.-M. (2005). Hollywood, The Pentagon and Washington: The Movies and National Security from World War II to the Present Day, Anthem Press.

The White House (19??). 42. William J. Clinton. http://www.whitehouse.gov/about/presidents/ williamjclinton, 11.05.2009.

Yalcinkaya, A. (1997). Sovyetler Birliği Döneminde Moskova ile Türk Topluluklarl İlişkileri (Kronolojik Çalışma), Yayın No: 23, Sakarya: Sakarya Üniversitesi Basımevi.

Derya Değer was a director of International Relations Office in Sakarya University and then has become a lecturer at the department of International Relations in Sakarya University, Sakarya. She lectures on the subjects of Academic and Business English. She graduated from American Culture and Literature Department in Ege University and had a post graduate education at International Relations Department at the Institute of Social Sciences in Sakarya University and she prepared thesis titled Hollywood Films Reflecting Middle East Policy between 1993 and 2008. Her thesis examines the relations between the foreign policy of the USA on the Middle East region and Hollywood between the years of 1993 and 2008. The films have been scrutinized from the point of view of political identity, security and gender matters. Stated in other words, the films have been analyzed from the perspectives of postmodernism and feminism.

CINEJ Cinema Journal: : The Relation Between Hollywood and The New...

Special Issue: 1 (2011) ｜ ISSN 2158-8724 (online) ｜ DOI 10.5195/cinej.2011.18 | http://cinej.pitt.edu 